\title{
Human Rights Relationship between the European Union and China: The EU Approach to the Post-Tiananmen Incident and Xinjiang Crisis in China
}

\author{
Mur-hamida Sapaih Eldani \\ Selçuk University, International Relations Faculty, Social Science Institute, Konya, Turkey
}

\section{Article history:}

Submitted: 8 January 2021

Revised: 13 March 2021

Accepted: 25 March 2021

\section{Keywords:}

China

European Union

Human rights

Tiananmen incident

Xinjiang crisis

\begin{abstract}
This paper specifically deals with the European Union and China Human Rights, Tiananmen, and Xinjiang. As a human rights promoter and protector, the EU turned its attention to the human rights violation issues in Tiananmen and Xinjiang. This work propels the readers to realize the EU's efficiency and approach on human rights issues. By reviewing literature works related to the study's theme, this review essentially examines the EU approaches in the post-Tiananmen and Xinjiang human rights dilemma. Also, it scrutinizes how the EU's Human Rights differ from China and its impact on their human rights relationship. It indicates that the EU response during the post-Tiananmen and Xinjiang crisis was relatively weak and insufficient. Correspondingly, the diverse concept of human rights between the EU and China and their conflicting views lessen their human rights negotiations and decrease the chance of stable human rights relations.
\end{abstract}

\subsection{Introduction}

The EU has an active role in propagating the universalization of values and norms (Zhimin, 2012). Also, the EU laws stipulate human rights' protection (TEU, Art. 6). Nonetheless, Human Rights is among the most controversial aspects and considered the most 'destabilizing' field on EU-China relations (Wang \& Song, 2016). The European Union and China diplomatic relationship started in 1975. After 1975, both parties collaborated in many trades, academic and cultural shifting (Dai, 2006). The Tiananmen incident became one of the most disturbing events that massively affect the relationship between the EU and China (Zhang, 2011). It caused an uncertain connection between them (Möller, 2002). On the other hand, another situation that gathered the EU's attention is the Xinjiang region's current human rights crisis. The relentless 'strike hard' campaign resulted in the rapid increase of immediate arrest and death sentences of the Uyghur in 1997-1999. This persecution continued until the 21st century (Clarke, 2010). Thus, human rights violations are becoming more proliferating worldwide.

This review allows us to realize the EU's human rights approach's efficiency by highlighting two significant events; the Tiananmen and Xinjiang crisis. This work aims to explicitly answer how the EU responds to the post-Tiananmen incident and the current Xinjiang crisis. Besides, by describing both actors' human rights ideas, we could scrutinize how the EU Human Rights differ from China and possibly see their underlying impact on EU-China Human Rights relations.

\subsection{Framework of the Study}

This study anchored on the EU approaches to human rights in Tiananmen and Xinjiang and the EU-China Human Rights concepts. Frosythe (2012) mentioned that human rights are globally recognized and routinized. Thus, giving attention to the idea of human rights became worldwide governance (Frosythe, 2012). Several declarations and treaties deal with the internationalization of human rights (Frosythe, 2012). Human rights norms became the center of historical insurrection. Besides, states such as in Europe perceived that international action to achieve human rights is more valuable than having absolute freedom in policy-making (Frosythe, 2012).

The EU approach to human rights abuses everywhere is strengthened by its laws protecting and promoting human rights. The Union's principles guide the EU actions in the global scene. At the Cold war's conclusion, the EU prepared human rights as part of their international cooperation agenda (Balfour, 2013). Human rights and democracy became part of the EU regional policies and universal thematic strategies. Thus, it pursues battles against the death penalty (Balfour, 2013). Aside from protecting human rights, the EU courts on human rights expand and promote gender 
equality in Europe and other countries like Russia (Malksoo \& Benedek, 2017). Furthermore, being a human rights and democracy defender, the EU has proven its commitment through a people-based approach during the post-Arab spring in 2011 (Peters, 2012).

The Tiananmen incident made human rights a political issue in China (Christiansen et al., 2019). As Kong cited, China's overwhelming condemnation also happened due to its human rights violation against its people. Tiananmen incident is considered a fable of the violent regime, a human narrative's heartbreak of popular protest, and employed a political lexicon and a crash of democracy and totalitarianism in the near end of the Cold war epoch (Kong, 2012). Tiananmen turned into an international drama through media venues and disclosed the PRC's brutality over its people (Kong, 2012). Meanwhile, Millward cited that the human rights issues, terrorism, religious freedom, and China's role in Central Asia brought Xinjiang into the media world (Millward, 2007). The 9/11 attack in the USA inspired the Chinese government to adopt harsh policies against the Uyghur in Xinjiang. China saw the Uyghur nationalism linked to terrorist organizations and a threat to Chinese sovereignty (Trédaniel \& Lee, 2018). China justified its adoption of harsh measures against the Uyghur in Xinjiang to fight terrorism and separatism in the country (Mangır \& Eldani, 2020). China has vehemently opposed the issue of terrorism and religious extremists since the 1990s. Islam's persecution is perceived as an opposition to Chinese rule (Cheng, 2011).

\subsection{Methods}

To reach this paper's objectives, the author reviewed reliable academic works beneficial to the study. The author examined writings from Chinese and Western authored-books and other related published works to avoid biases of opinions and views. Besides, the author utilized references based on the official EU pages and human rights study-based materials. Further, this research considered the human rights dialogue of the $\mathrm{EU}$ and China within specific periods to assess the possible condition of their human rights relations. Nevertheless, the paper's scope is limited to particular writings on the EU approach to China's human rights activities covering Tiananmen and Xinjiang. Hence, it does not cover all human rights literature.

\subsection{Discussion}

\section{A. Human Rights comparison between the EU and China}

In the early twentieth century, Chinese people inculcated human rights in their struggle for modern China and connoted human rights as progress. Nevertheless, most in power rejected this idea due to a lack of global attention, but not until 1948. The creation of the UN (United Nations) forced China to heed and adopt human rights concepts. The PRC (People's Republic of China) became used to human rights discussions in the 1970s but could still dismiss it for being out of the UN system. Hence, in the late 1920s, China ignored human rights for not fitting in a revolutionary society and a bourgeois slogan (Svensson, 2002). In early Chinese articles in the 1900s, the Chinese recognized the endowed rights that are believed to be inherent. Thus, Chinese writers described rights as 'due rights' enjoyed by a human in nature. Some writers saw these human rights as original rights and possessed by all individuals regardless of social status. However, this teaching was at odds with the Confucian tradition, which is hierarchical (Svensson, 2002). Some Chinese writers criticized Chinese traditional human rights due to its family rights' focusing instead on an individual (Svensson, 2002).

The modern human rights ideas or concepts have been impost by the West in the later $19^{\text {th }}$ century. Meanwhile, some perceived human rights as the West's principles and are being used and served as a tool for the Western intervention in China's affair in the late '70s (Pan, 2012). The idea of human rights is associated initially with the West. How Chinese people acquired these rights is believed to be a cross-cultural borrowing product instead of foreign values' imposition (Svensson, 2002). The assimilation of human rights to the PRC is entwined with writing and revising its history to support human rights (Svensson, 2002).

\section{China's Concept of Human Rights}

China harbors culture and Confucianism (Svensson, 2002). Human Rights in China is outlined back to Confucianism. Even though human rights in China had not formally assimilated to any legal papers, human rights became stable in China after its establishment. The Chinese Communities, in the 
1990s, had accepted human rights ideas, and the human rights theories in China had consequently materialized. China's sources of human rights include traditions, history, and, likewise, influenced by Marxism (Pan, 2012).

Under Confucianism, they highlighted collectivism. Collectivism indicates an individual's duty towards other groups. Moreover, under the collectivity principle, China concurred on the idea of sacrificing certain rights for the wellbeing of the masses (Pan, 2012). Chinese Human Rights Concept is more on relativism. China equally denied natural law's relationship to human rights, as the West claimed it to be interrelated. China also stands for the non-detachable nature of socio-economic ideas to human rights. The socio-economic structure and the cultural development are considered human rights matters, as China agrees with Karl Marx's ideologies. They regarded development in economics as an essential way for human rights advancement. The Chinese saw culture as a primary mechanism to influence China's human rights practices (Pan, 2012).

The enforcement of human rights is dependent on China's national condition. As similarly mentioned, it gave courtesy to socio-economic progress. Human Rights is more on the effort of guaranteeing the right of subsistence. Congruently, they claimed the China's version of human rights' ideas is more realistic than emphasizing democracy and liberty alike. Thus, the Chinese are momentously inclined to economic development objectives. After the economic matter, human rights could finally be incorporated into political and liberal matters (Wang \& Song, 2016; Svensson, 2002). China is persuaded to satisfy the needs of its billion constituents. Besides, China's economic plan and the Chinese people's livelihood are part of human rights fulfillment (Zhisang, 2011).

In the first twentieth century, China accepted human rights concepts such as independence and sovereignty. Besides, racism, imperialism, genocide, and colonialism are labeled as violations of human rights. The notion of decolonization and self-determination are also necessary rights. On the other hand, the Leninist principle is equally significant in human rights talks. China joined the UN's Human Rights organization and took part in a global society (Inboden \& Chen, 2012). The PRC's history and national identity shaped the country. For an extensive period of 35 years, China has been cooperating and participating in human rights matters. Besides, in 1997-1998, China concluded international human rights covenants (Wang \& Song, 2016).

\section{EU's concept of Human Rights}

In contrast, the Europeans recognized the men-state clashes and the states that promoting human rights has an overbearing phase to protect people. Individual rights or individualism are significantly acknowledged by the Europeans (Pan, 2012).

The Europeans believed in universalism and held cultural diversity's necessity. The Europeans correspondingly heed these principles to mediate in the third worlds' human rights situations. Thus, the EU misunderstood and perceived rehabilitation policies and family planning as violations of rights (Pan, 2012). Europeans' human rights concept is associated with natural rights, which implies its innate nature in men. These rights were inalienable and inviolable (Svensson, 2002). As cited, the West believed in the abstract nature of political and civil rights and their universality. Hence, social right is secondary and not viewed universally, which China oppositely saw as concrete as an economic right (Svensson, 2002). Meanwhile, the EU is committed to its duty of elevating all possible facets of human rights (Wang \& Song, 2016).

Human Rights embodies all magnitudes of life. For instance, political rights should not be given up in exchange for economic rights. From the Chinese perspective, as mentioned above, people's ability to rule their nation and won against foreign domination is considered an economic achievement. In this setting, political rights are likely to be achievable (Zhisang, 2011).

The EU and China differ in several aspects. They are geographically distant and have uncommon societal values. China does not give more highlights on humanitarian intervention principles (Wang and Song, 2016). The EU and China have outstanding views on rights and obligations. For instance, the EU prioritized rights under human rights, while China argued that obligations are much heavier than rights. Europeans claimed human rights are the same as sovereignty and believed in people's freedom and liberations. Compare to the EU; China argued violations of rights are trigger by the loss of sovereignty. Thus, this sovereignty of states promotes human rights. China also relied on the non-interference of sovereignty. At the same time, the EU reversely concurred on the significance of interference to preserve human rights (Pan, 2012). 
The Western promotion of human rights has created some doubts due to its Western Philosophy origin. Although the EU saw China being an imperative state, it still questions its potential consideration of the EU customs and values (Wang \& Song, 2016). Since the $21^{\text {st }}$ century, the language of human rights became more incorporated or appropriated into PRC. Nevertheless, talks on human rights violations are not much abated. Fortunately, individual human rights in China had strengthened through China's signing of the International Covenant on Civil and Political Rights (ICCPR) and the International Covenant on Economic, Social and Cultural Rights (ICESCR) (Svensson, 2002). The PRC became a certified member of the UNCHR (United Nations Commission on Human Rights) in 1982. However, China does not always agree with Western human rights practices. The concept of state interference in human rights implementation and human rights globalization is undesirable to China because of its probable negative impact on the PRC's vision (Inboden \& Chen, 2012). The seizing of human rights in China underdone conscious effort from its institutions to defend its vision and human rights records. Besides, since 1991, China issued White papers on human rights policies. These policies protect China's Human Rights conception and attempt to refute Western criticisms of its human rights (Svensson, 2002).

\section{B. EU as a Human Rights actor}

One of the European Union's normative ethics is human rights, which the EU desire to promote worldwide (Manners, 2008). The Treaty of Lisbon of 2009 (Borreschmidt, 2014), the European Security Strategy (ESS), and the Common Foreign and Security Policy (CFSP) served as guidelines for promoting human rights. The EU similarly possessed practical tools to fight women's violence, torture, and the death penalty (Yazgan, 2017; Möller, 2002).

The Treaty of Lisbon is a series of amendments now called the TEU (Treaty on European Union). Moreover, the TEU (Art.2) states the EU's respect for human rights. The treaty expanded the EU's role in protecting human rights (TEU, 2012; Open Society Foundation, 2011). The European Security Strategy (ESS) reiterates that international order is based fundamentally on respect for human rights and freedoms. ESS gave power to the EU institutionalization of human Rights and covers its external actions. It also reiterates that human rights and freedom are the basis of international order (Debiel and Werthes, 2006). Under Art. 21 (2) of CFSP provisions, the EU's role in advancing human rights in the international scene is emphasized (TEU, 2012). Thus, Under Article 21 of TEU, the EU also seek in building partnership with third countries and pursue standard policies for safeguarding fundamental values and other similar objectives (TEU, 2012).

To inculcate human rights, the EU measures such as financial and trade agreements are being offered to the third world. Under CFSP principles, condemnation of violence is labeled as the weakest. The most potent is the "arms embargo and contract suspensions," which falls under 'diplomatic sanctions.' Lastly is the extent of approving military interventions to terminate human rights violence (Elgström \& Smith, 2006). These EU actions were considered reinforcement by either reward or punishment (Elgström and Smith, 2006).

In line with the EU-China Partnership Cooperation Agreement, and through dialogue, the EU had supported reforms in China. Thus, the EU anticipated this step helps China hold more human rights responsibilities (Zhou, 2016). To ease human rights' disagreements, the EU is willing to have progressive human rights talks. China likewise desired to cooperate (Zhou, 2016). China got interested in dialogue with the West than talking on human rights with its constituents (Svensson, 2002).

\section{The Post-Tiananmen Incident in $\mathbf{1 9 8 9}$ and the European Union response}

In 1989, the Beijing students demonstrated in Tiananmen Square calling for liberalization and economic reform. This demonstration was also part of the death commemoration for Hu Yaobang, a reformer. However, this simple movement sooner evolved into an influential protest. On May 4, students demanded the PRC for political and economic reform's acceleration to guarantee freedom and battle corruption (Nathan, 2001). Afterward, the students engaged in hunger strikes, and some intellectuals also decided to join. This student movement even caught the attention of the foreign press. The students gained up to ten million citizen's supports and demanded a response from the government. The PRC engaged with some dialogue (Nathan, 2001). However, the final response was martial law (Nathan, 2001). From May to June, the PLA (People Liberation Army) allegedly killed civilians, which fueled more anger and fear among protesters $(X u, 2020)$. The rioters presumed 
committed violence and then shot to death. Many were injured and killed in the riots $(X u, 2020)$.

From May to June of 1989, the Sino-European relationship was frozen due to the Tiananmen incident (European Parliament, 2011). The EU imposed an economic and political embargo and highlevel visits suspension (Vogt, 2012). However, in the middle '90s, human rights problems were delinked to MFN (Most Favored Nation) issues by late president Bill Clinton. Thus, the 1997 visit of President Jiang Femin to Washington exemplified China's revival victory in the international realms. This significant visit relinquished the sanction and pressure which was placed on China. China decided to abide by international agreements in line with human rights and arm controls. Thus, it signed the ICESCR to breakthrough sanctions from western isolation (Vogt, 2012).

The first 12 original member states (Netherlands, Italy, Germany, France, Ireland, Luxembourg, Denmark, UK, Spain, Greece, Belgium, and Portugal) of the EU gathered in Madrid and strongly condemned the brutality in the Tiananmen. On June 27 (1989), they adopted high-level contract suspensions, military cooperation among the members, raising human rights issues in the international fora, reducing cooperative programs, and arms trading embargo (Baker, 2002). In 1990, the EU gradually eased high-level contact restrictions and cooperation projects. However, they maintained an arms sales embargo and cooperation in the military. They opted for this way of easing restrictions because they believed in the productive Chinese role during the Gulf crisis and its assurance and commitment towards human rights (Baker, 2002). They also decided to raise China's human rights issue to spread awareness internationally (Baker, 2002).

In the same year (1990), the member states co-sponsored resolution condemning human rights records in China. Correspondingly, the EU members co-sponsored similar resolutions every year. This resolution signifies the notable success of the CFSP and EPC (European Political Cooperation). Nevertheless, Spain, Italy, Germany, and France discontinued their support on the resolution. Also, the French's changes of policies influenced France's reluctance towards China. Afterward, the French president visited Beijing and signed export contracts to redeem their relations. On the other hand, nine EU members and Denmark continued sponsoring the resolution, which caused China's retaliation of canceling its Vice-Premier visits to the sponsoring states. Later in 1998, they decided to withdraw the resolution and instead agreed with China on the resumption of human rights dialogue (King, 1999). The EU Commission opted to believe that dialogue is more productive than condemnation which China discards (King, 1999). Thus, China agreed on signing the Convention on Civil and Political Rights of the United Nations. This deal implies its strong will to preserve human rights (FMPRC, 2014).

The EU criticized the despotism of democracy and necessitated discontinuing the PRC's violent treatment against those individuals who stand for egalitarian rights. The EU decision in arms embargo is legally binding under the EU law and also applied to China. Nevertheless, products' prohibition was not part of the embargo. The embargo was exclusive for partial repression. Between 2003 to 2005, the European Union lifted the embargo. German and France's leaders initiated this idea due to their interest in China's defense and aircraft industries. For China, it was a discriminative action or step. The initiative was disagreed with by the European Parliament due to the pressure from Washington (USA). The stalemate occurred, and the embargo remained for a quarter-century (Maull, 2017).

The arms embargo resulted in a trading war. China's counteractions were against importing materials for solar panels, a crucial trade matter for both parties. China also put diplomatic pressure on the EU and threaten to investigate imported cars of Germany to China. This tactic worked and forced other EU members led by Germany to go against EU Commission. Berlin likewise led a coalition to make settlement negotiations with China (Maull, 2017). Thus, the institutionalized dialogue with China is solely stipulated for the EU's human rights dealing with third countries (Vogt, 2012).

In response, as previously said, in 1995, the Commission on Human Rights (CHR) had proposed a resolution about the human rights concern in China. The respectable members of the UN united together as the co-sponsors of the selected action. Nevertheless, the motion for "no action" became dominant due to tied votes. In 1996, the exact motion for the resolution came again. The EU members backed up the resolution yet became unsuccessful due to the majority's "no action" vote. In 1997, the General Affairs Council conveyed its readiness for dialogue cooperation and assessed China's compliance and fulfillment to human rights standards. Afterward, in 1998, the EU members opted not to sponsor any resolution, which led to China's inclination to cooperate on dialogues on human rights and to work together in the future. Hence, before this year, until 2000, the EU finally decided not to sponsor resolutions (Baker, 2002). 
Furthermore, the first dialogue about human rights was held in Brussels in the first month of 1995, and it was against the EU regarding the lobbying of resolution. The following year was held in Beijing. However, the prominent members of the EU still got the idea of making a resolution, and China got heard of this plan. As a result of knowing this EU's probable plan, and as China realized it failed to divert the resolutions and criticisms, it withdrew from the dialogue. However, in 1997 October, the EU-China dialogue took place in New York. Hence, the same event was followed in Luxembourg.

Although the extensive dialogue happened until 2000, the EU members' frustration was triggered due to a lack of concrete results out of the dialogue. Besides, in 2000, as the General Affairs of Council on China mentioned, the talks or dialogue failed to produce concrete results. Everything was devoid of value (Baker, 2002). From 2004 to 2005, the EU-China energetic relationship revived again when the European Commission ceased the embargo (Callahan, 2007).

Recently, in the commemoration of the Tiananmen incident, on the 30 years of its existence on June 4, 2019, the European Union still expressed grieve and condolences to the victims of the said event. They hope for the PRC collaboration to follow its recommendations and for the due and rightful process of those detained. Thus, European Union stressed its devotion to human rights promotion and its partnership with China (EEAS, 2019).

\section{Xinjiang crisis and the EU response}

Xinjiang province is one of China's critical areas. It is wholly called as Xinjiang Uygur Autonomous Region (XUAR). The Uygur, with a Turkic foundation, dominated the region, and their supposed engrossment in terrorism got the Westerners' attention. For several decades, they were hunted with fears but only in the mid'90s that Uyghur sought assistance and became known in Western societies (Hagan, 2010).

Due to fear of separatism and terrorist activities, the PRC implemented serious measures in Xinjiang province. Minority groups like Uyghur, including other minorities like Kazakhs, were imprisoned. The international community saw these measures as cultural genocide. As part of the EU counteraction, the Xinjiang region has been labeled 'no rights zone' in August 2018. Access for monitoring the incident in Xinjiang was also requested, and the prominent members of the EU likewise offered Asylum for the Uyghurs. Thus, the existing imprisonment campaign in China was congruently condemned by the EU (Marques, 2019).

In the year 2017 of June 22 and 23, the $35^{\text {th }}$ human rights dialogue between the EU and China took place in Brussels. Here, the EU emphasized the decline of civil and political rights in China. This decline manifested through illegal, arbitrary detention, restriction on the freedom of expression, and criminal justice system. Freedom of religion and minority rights in the Xinjiang and Tibet region were also discussed during the dialogue (EEAS, 2017). During the $36^{\text {th }}$ dialogue, held in 2018, Beijing, China's achievements and failures in line with its human rights practices were mentioned. The EU became particular with the decline of civil and political rights in PRC. Meanwhile, the progress in social and economic rights in China was correspondingly recognized in the event. The parties had open arguments on human rights issues in China and the possible cooperation to human rights matters and business. Thus, the 're-education camp' of the Uyghur was also a particular concern of the participants, promoting their rights and freedom. Like the $35^{\text {th }} \mathrm{HR}$ dialogue, the EU gave notice to the country's civil and political rights, including issues of deterioration of rights. The detention of scholars and other personalities and the massive occurrence of illegal arrests since 2015 were stated. The Uyghur rights and the rights of other minority groups had been importantly revealed (EEAS, 2018a).

In 2018 (October), the EU Commission Vice-President, Federica Mogherini, delivered a speech and debated for resolution. The concerned resolution is about the Uyghur and Kazakh's massive imprisonment in China. The EU representative stated the EU's worries on the ongoing immense detention of the minorities in China's re-education camps, including their surveillance and travel restrictions. The EU called for cooperation and consideration of the minorities' rights and demanded respect for fundamental rights, including in Xinjiang (EEAS, 2018d).

The European Parliament appealed to China to ease imprisonment and punitive actions against the minorities (Uyghur \& Kazakh). The EU also called for acknowledging and recognizing the human rights agreements and covenants they had concluded (European Parliament, 2018). 
In the summit held in 2019, chances are given for both EU and China to negotiate more on the Xinjiang condition. Nonetheless, the EU unsuccessfully addressed the main issue. Besides, the international organization, the Human Rights Watch, harmoniously asked the EU for its more tangible actions against the ubiquitous abuse of human rights in China. In the April EU-China dialogue, another human rights talk took place; however, this strategy did not work for both of them, especially China. The human rights abuses in Xinjiang are still on fire because China failed to prove the human rights progress in the region. China subsequently declined to entertain sessions with other civil organizations. The EU received pressure from these organizations to maximize the stressing of human rights violations and stress for political detainees' release. According to Amnesty International's director, the EU must heed their quiet diplomacy towards China's human rights. Besides, this Amnesty also suggested urgency (Human Rights Watch, 2019).

In the 2019 Summit, the EU-China devoted themselves to strengthening partnerships, supporting trade, and multilateralism. Furthermore, they committed to environmental cooperation, and in line with human rights promotion, the continuation of the EU-China dialogue was understored by Donald Tusk. He expressed his apprehension on human rights and raised awareness on the individual number of cases (European Council, 2019).

On April 17, 2019, European Parliament made another joint motion concerning China's minorities. Not far from former resolutions, the EU called China to end illegal detentions and take heed towards the agreements on human rights matters. It also provoked other EU members' courtesy to take responsibility and actions over China's situation (European Parliament, 2019).

Moreover, China got international condemnation similar to the reports mentioned above. The UN demanded the camp's access in Xinjiang, and the EU necessitated deference for religion by the PRC. The organization subsequently asked for policy alterations in Xinjiang. Thus, other Human Rights movement similarly necessitated closing the camp and asked China to be responsive to the missing Uyghur (Council on Foreign Relations, 2019).

\subsection{Conclusion}

In the post-Tiananmen incident, the EU strongly condemned China's brutal activities and imposed an arms embargo as part of its diplomatic sanction. However, the measure did not eventually last. Despite several dialogues held and the resolution's bargaining, the EU still ended not pursuing the countermeasure. Similarly, in the EU-China series of dialogues in the summits, the EU's condemnation against China's activities to the Uyghur in Xinjiang became redundant, and China did not take heed of the EU's appeals. As previously cited under the CFSP, condemnation of violence is the weakest. The strongest or most potent of the EU action includes military intervention and the arms embargo, which are diplomatic sanctions. Nonetheless, the EU did not committedly advance these more robust measures.

Under the said circumstances, concerning how the EU responded to human rights issues in China, both in the post-Tiananmen and in the Xinjiang, we could say the EU approaches were relatively weak and insufficient. Perhaps, the EU needs to be more committed to protecting human rights and not being driven or influenced by any economic interests.

On the other hand, although the EU and China both joined international human rights conventions and recognized social, political, civil, and economic rights, both actors have diverse outlooks on human rights concepts. Human Rights in China is more on social and economic aspects, whereas the EU focuses more on civil. China perceives economic progress as a significant matter which might fetch advancement of other aspects of rights. Also, history and culture shaped and influenced China's human rights. The EU, in contrast, focuses more on the universalization of its perceived concept of human rights. Thus, the diverse concepts of human rights, cultural incompatibility, and non-adjustable position in developing a common and shared notion of human rights contributed to the EU's lapses in having stable human rights relations with China. 


\section{REFERENCES}

Baker, P. (2002). Human rights, Europe and the People's Republic of China. The China Quarterly, 169, 45-63.

Balfour, R. (2013). Human Rights and Democracy in EU Foreign Policy: The Cases of Ukraine and Egypt. New York: Routledge.

Borreschmidt, N. (2014). The EU's Human Rights Promotion in China and Myanmar: Trading Rights for Might ( Paper No. 05). College of Europe, Department of EU International Relations and Diplomacy Studies. Retrieved from http://aei.pitt.edu/58680/2/edp_5_2014_borreschmidt.pdf

Callahan, W. (2007). Future imperfect: the European Union's encounter with China (and the United States). Journal of Strategic Studies, 30(4-5), 777-807.

Cheng, J. (2011). Whither China's Democracy? Democratization in China since the Tiananmen Incident. City University of HK Press.

Christiansen, T., Kirchner, E. ., \& Wissenbach, U. (2019). The European Union and China. Macmillan International Higher Education.

Clarke, M. (2010). Widening the net: China's anti-terror laws and human rights in the Xinjiang Uyghur Autonomous Region. The International Journal of Human Rights, 14(4), 542-558.

Council on Foreign Relations (2019). China's crackdown on Uighurs in Xinjiang. Retrieved from https://www.cfr.org/backgrounder/chinas-crackdown-uighurs-xinjiang

Dai, X. (2006). Understanding EU-China relations: an uncertain partnership in the making (Paper. No.1) University of Hull, Department of Politics and International Studies.Retrieved from https://citeseerx.ist.psu.edu/viewdoc/download?doi=10.1.1.530.8803\&rep=rep1\&type=pdf

Debiel, T. and Werthes, S. (2006). Human Security on Foreign Policy Agendas: Changes, Concepts, and Cases. Duisburg: Institute for Development and Peace.

Elgström, O. and Smith, M. (2006). The European Union's roles in international politics: concepts and analysis. London: Routledge.

European Council (2019). EU-China Summit. Retrieved from https://www.consilium.europa.eu/en/ meetings/international-summit/2019/04/09/

European External Action Service (EEAS). (2017). Human Rights Dialogue between the European Union and China. Retrieved from https://eeas.europa.eu/headquarters/headquartershomepage/28768/human-rights-dialogue-between-european-union-and-china_en

European External Action Service (EEAS). (2018a). The European Union and China held their annual Human Rights Dialogue. Retrieved from https://eeas.europa.eu/delegations/iran/48217/ european-union-and-china-held-their-annual-humanrights-dhaganialogue_en

European Union External Action (EEAS). (2018d). Speech on behalf of the High Representative/VicePresident Federica Mogherini at the European Parliament urgency debate on "Mass arbitrary detention of Uyghurs and Kazakhs in the Xinjiang Uyghur Autonomous Region". Retrieved from https://eeas.europa.eu/headquarters/headquarters-homepage/51670/speech-behalfhighrepresentativevice-president-federica-mogherini-european-parliament-urgency_en

European External Action Service (EEAS). (2019). The European Union and China held their 37th Human Rights Dialogue. Retrieved from https://eeas.europa.eu/delegations/iran/60545/ european-union-and-china-held-their-37th-human rights-dialogue_en

European Parliament (2011). EU-China Trade Relations. Retrieved from https://www.europarl.europa. eu/RegData/etudes/etudes/join/2011/433861/EXPO-INTA_ET(2011)433861_EN.pdf

European Parliament (2018). European Parliament 2014-2019 Joint Motion for Resolution. Retrieved from http://www.europarl.europa.eu/doceo/document/RC-8-2018-0460_EN.pdf

European Parliament (2019). Joint motion for a resolution. Retrieved from http://www.europarl. europa.eu/doceo/document/RC-8-2019-0255_EN.pdf

Frosythe, D. (2012). Human Rights in International Relations. New York: Cambridge

Hagan, M. (2010). The human rights repertoire: Its strategic logic, expectations, and tactics. The International Journal of Human Rights, 14(4), 559-583.

Human Rights Watch. (2019). EU: Make China's Rights Crisis a Summit Priority Forcefully, Publicly Raise Xinjiang, Imprisoned Activists. Retrieved from https://www.hrw.org/news/2019/04/04/eumake-chinas-rights-crisis-summit-priority

Inboden, R. S. and Chen, T. C. (2012). China's Response to International Normative Pressure: The Case of Human Rights. The International Spectator, 47(2), 45-57. 
King, T. (1999). human rights in European foreign policy: success or failure for post-modern diplomacy? European Journal of International Law, 10(2), 313-337.

Kong, B. (2012). Tiananmen Fictions outside the Square: The Chinese Literary Diaspora and the Politics of Global Culture. USA: Temple University Press.

Malksoo, L. and Benedek, W. (2017). Russia and the European Court of Human Rights: The Strasbourg Effect. New York: Cambridge University Press.

Mangır, D. and Eldani, M. (2020). Human Rights Conditions in Xinjiang Uyghur Autonomous Region (XUAR) China. In Güngör, Ayşegül (Eds.), Current Approaches In Social, Human and Administrative Sciences. Turkey: IKSAD Publishing House.

Manners, I. (2008). The normative ethics of the European Union. International affairs, 45-60.

Marques, D. (2019). The EU, China, and Human Rights in Xinjiang: Time for a new approach. Retrieved from https://ecfr.eu/article/commentary_the_eu_china_and_human_rights_in_ xinjiang_time_for_a_new_approac/

Maull, H. (2017). The politics of the EU: China's relationship with Europe. Asian Journal of Comparative Politics, 2(1), 55-69.

Millward, J. A. (2007). Eurasian crossroads: a history of Xinjiang. New York: Columbia University Press.

Ministry of Foreign Affairs of the People's Republic of China (FMPRC). (2014). The Signing of the International Convention on Civil and Political Rights by the Chinese government. Retrieved from https://www.fmprc.gov.cn/mfa_eng/ziliao_665539/3602_665543/3604_665547/t18041.shtml

Möller, K. (2002). Diplomatic relations and mutual strategic perceptions: China and the European Union. The China Quarterly, 169, 10-32.

Nathan, A. J. (2001). The Tiananmen Papers. Forxcxzvceign Affairs, 80(1), 2

Open Society Foundation (2011). Human Rights in the EU: how the Lisbon Treaty could help. Belgium: Open Society Foundation.

Pan, Z. (2012). Conceptual gaps in China-EU relations: global governance, human rights, and strategic partnerships. Great Britain: Palgrave Macmillan.

Peters, Joel. (Eds.). (2012). The European Union and the Arab Spring: promoting democracy and human rights in the Middle East. New York: Lexington Books.

Svensson, M. (2002). Debating human rights in China: A conceptual and political history. USA: Rowman \& Littlefield.

Treaty on European Union (TEU). (2012). Consolidated Version of the Treaty on European Union. Retrieved from https://eur-lex.europa.eu/resource.html?uri=cellar:2bf140bf-a3f8-4ab2-b506fd71826e6da6.0023.02/DOC_18format=PDF

Trédaniel, M. and Lee, P. K. (2018). Explaining the Chinese framing of the "terrorist" violence in Xinjiang: insights from securitization theory. Nationalities Papers, 46(1), 177-195.

Vogt, R. (2012). Europe and China: strategic partners or rivals? (Vol. 1). Hong Kong: University Press.

Wang, J. and Song, W. (2016). China, the European Union, and the International Politics of Global Governance. London: Springer.

$\mathrm{Xu}, \mathrm{B}$. (2020). Listening to thunder in the silence on Tiananmen: Politics and ethics of the memory of the June 4 Movement. China Information. Retrieved from https://doi. org/10.1177/0920203X20956561

Yazgan, H. (2017). European Union's Human Rights Policy: An Analysis From External Relations Perspective. Adam Academy Journal of Social Science, 7(1), 51.

Zhang, L. (2011). News media and EU-China relations. New York: Springer.

Zhimin, C. (2012). Europe as a global player: a view from China. Perspectives: a review of Central European affairs(2), 7-29.

Zhisang, C. (2011). Rethinking on China's human rights ideology. International Critical Thought, 1(4), 408-415.

Zhou, H. (2016). China-EU Relations: Reassessing the China-EU comprehensive strategic partnership. Beijing: Springer.

\section{Correspondence:}

MUR-HAMIDA SAPAIH ELDANI

eldanimurhamida@gmail.com

https://orcid.org/0000-0001-5183-1144 